\title{
Polynevromyopati hos intensivpasienter
}

\section{Mange pasienter får pr oblemer med nevr omuskulær svikt under et intensivforløp. Muskelatr ofi og muskelsvakhe $t$ gir dårlig mobilitet, og svekkelse av muskulatur kan vedvar e i flere år etter sykdomsdebut.}

\section{Forfattere}

\section{Linh My Chau}

Intensivsykepleier

Høgskolen i Østfold

\section{Anne-Mette Nygaard}

Høgskolelektor, intensivsykepleier

Høgskolen i Østfold

\section{Ann-Chatrin Leonardsen}

Førsteamanuensis

Høgskolen i Østfold

\section{Nøkkelord}

\section{\begin{tabular}{l|l|l|l} 
Nevromuskulær Intensivpasient Komplikasjon Forebygging CIPNM & .
\end{tabular}}

Sykepleien 2017 105(63849)(e-63849)

DOI: https://doi.org/10.4220/Sykepleiens.2017.63849

\section{HOVEDBUDSKAP}

Enkelte grupper intensivpasienter har høy risiko for å utvikle polynevromyopati. Det er i dag ingen spesifikk behandling av tilstanden. Tidlig identifisering, forebygging og mobilisering er derfor viktige sykepleieoppgaver. Denne artikkelen påviser risikofaktorer, forebyggende og behandlende sykepleietiltak. 
64 prosent av intensivpasienter har problemer med mobilitet etter intensivforløpet (1). Dette kunne ha vært redusert eller unngått med økt kunnskap.

Polynevromyopati (Critical illness polynevromyopati CIPNM) kan utvikle seg i løpet av kort tid hos pasientgrupper med høy risiko. Dette kan gjelde for pasienter med systemisk inflammatorisk responssyndrom (SIRS), sepsis, flerorgansvikt, hyperglykemi og/eller langvarig respiratorbehandling. Kunnskap om og forståelse for denne tilstanden er nødvendig for å gjenkjenne risikogrupper samt for å kunne starte tidlig med forebyggende tiltak.

\section{NEVROMUSKULAER DYSFUNKSJON HOS INTENSIVPASIENTER \\ CIP: Critical illness polynevropati. Aksonal degenerasjon og forstyrrelse i det perifere nervesystemet \\ CIM: Critical illness myopati. Økt nedbrytning av muskulatur eller mangel på syntese av muskelprotein \\ CIPNM: Critical illness polynevromyopati. En tilstand av nevromuskulær dysfunksjon som er preget av muskelsvakhet og muskelatrofi (2).}

\section{Nevromuskulær svikt}

Critical illness polynevromyopati - CIPNM- beskriver en tilstand av nevromuskulær svikt hos kritisk syke. Tilstanden er karakterisert med muskelatrofi og muskelsvakhet. CIPNM er en samlebetegnelse for critical illness polynevropati (CIP) og myopati (CIM) (2). 
Inntil 70 prosent av sepsispasienter kan få CIPNM (3). Tilstanden kan utvikle seg i løpet av en uke hos ventilerte pasienter, og i løpet av to til fem dager ved sepsis (4). Sengeleie kan gi 40 prosent tap av muskelstyrke i løpet av den første uken, og dette er forsterket hos kritiske syke (5). Utvikling av dette vil få konsekvenser for intensivpasienten både under intensivoppholdet og etter utskriving. Svak respirasjonsmuskulatur gjør at det blir vanskelig for pasienten å avvenne seg fra respirator. Dette kan føre til forlenget sykdomsforløp. Polynevromyopatien kan også vedvare i flere år etter utskrivning. Dette begrenser pasientens mulighet for bevegelse og fysisk aktivitet, og fører til langvarig opptrening og rehabilitering (2).

\section{三 «Metoder for diagnostikk er blant annet elektromyografi (EMG) og muskelbiopsi.»}

Metoder for diagnostikk er blant annet elektromyografi (EMG) og muskelbiopsi. EMG registrerer muskelaktivitet i tverrstripet muskulatur i hvile og ved frivillig kontraksjon av muskelen. Det er vanskelig å registrere elektrisk aktivitet i musklene hos pasienter med ødemer eller utilstrekkelig muskelsammentrekning (6). En fullstendig utredning med nevrologisk undersøkelse forutsetter at pasienten kan medvirke til klinisk nevrologisk undersøkelse. Det er vanskelig hos respiratorpasienter eller pasienter med redusert bevissthet (7). Det finnes også scoringsverktøy som «The Medical Research Council sum score», som kan benyttes initialt for å måle muskelkraft hos bevisstløse pasienter hvor man mistenker CIPNM, men verktøyet er ikke oversatt og validert til norsk. Utvidete undersøkelser som serum kreatinin-nivå og muskelbiopsier kan også bidra til å stille diagnosen. Differensialdiagnoser kan for eksempel være Guillain-Barré syndrom, metabolske eller toksiske nevropatier, eller nevropati forårsaket av feil- eller underernæring (8). 


\section{Patofysiologi}

De senere år har det skjedd en enorm utvikling med å kartlegge de patofysiologiske prosesser omkring utviklingen av CIPNM (8). Mekanismene er komplekse og skyldes strukturelle og funksjonelle endringer og forstyrrelser, både i nerver og muskler. CIP skyldes degenerasjon av nervecellens aksoner med tilhørende forstyrrelser i det perifere nervesystemet. CIM skyldes i hovedsak muskelatrofi på grunn av økt nedbrytning av muskulatur eller mangel på syntese av muskelprotein. Muskelatrofi hos intensivpasienter kan også komme av immobilitet, betennelse, underernæring/malnutrisjon og nedsatt mikrosirkulasjon, i tillegg til metabolsk derangering, reversibel nervekanalpatologi og bioenergetisk dysfunksjon $(3,8)$.

\section{Symptomer}

De dominerende symptomene ved CIPNM er perifer muskelsvakhet og muskelatrofi (2). Muskelsvakhet kan forekomme i alle deler av kroppen, som nakke, skuldre og overkropp, men er mest uttalt i ekstremitetene. Dette kan være så omfattende at pasienten helt mister evnen til viljestyrt muskelkontraksjon (7). Andre symptomer kan være bortfall av dype senereflekser eller smertefulle pareser. Respirasjonsmuskulaturen blir også rammet slik at det blir vanskelig å avvenne pasienten fra respirator (2). Dysfunksjon i diafragma nedsetter pasientens evne til å kompensere ved økt respiratorisk belastning på grunn av lungeskader eller væskeoverskudd, og dette assosieres med økt mortalitet og morbiditet (9).

Brennende og kriblende fornemmelse i ekstremitetene er vanlig i et tidlig sykdomsforløp ved CIP. Tilstanden kan forverres, slik at berørings- og smertesansen også blir berørt. Pasienten kan ha sensibilitetsforstyrrelser, beskrevet som en følelse som minner om å gå på puter eller myke kuler (10).

\section{Risikofaktorer}


Nesten 50 prosent av intensivpasienter som utvikler CIPNM har sepsis, MODS eller langvarig respiratorbehandling og de har ofte et betydelig forhøyet blodsukker $(3,4,11)$. Bruk av kortison har også vært en påvist risikofaktor (12). Andre og mindre konsistente risikofaktorer man har funnet i ulike studier er hyperpyreksi, hyperosmolaritet, hypoalbuminemi, hypoksi, hypotensjon, hyper-/hypokalsemi, kvinnelig kjønn, høy alder, nyresvikt, nyretransplantasjon, parenteral ernæring og behandling med vasopressor (9).

\section{三 «Det er viktig å se etter tegn på CIPNM når pasienten er mer våken.»}

Sykepleiere bør observere og vurdere muskelstyrke, muskeltonus og senereflekser, men det er sjeldent mulig å observere symptomer på CIPNM hos dypt sederte pasienter (12). En dypt sedert pasient vil ikke reagere på verbal stimulering, og har medikamentelt bortfall av reflekser. Det er derfor viktig å se etter tegn på CIPNM når pasienten er mer våken. Ved lett sedasjon er det forventet at pasienten skal kunne reagere på verbal stimulering og ha intakte reflekser (2). Daglig vekking innebærer kortvarig avbrytelse av sedasjon slik at det er mulig å kommunisere og vurdere pasientens bevissthetsnivå samt nevrologiske status. Daglig oppvåkning forutsetter at pasienten får sedasjon med kort halveringstid (13).

\section{Forebyggende tiltak}

\section{Oppfølging av blodglukose}


Hyperglykemi er ikke uvanlig ved kritisk sykdom.

Akutt kritiske syke er utsatt for både fysisk og psykisk stress, noe som fører til økt utskillelse av

stresshormoner. Dette vil gi økt utskillelse av glukose og redusert insulinproduksjon. Risikoen for hyperglykemi øker når intensivpasienten i tillegg får tilførsel av store mengder med karbohydrater (2). Hyperglykemi kan påskynde utviklingen av organsvikt og økt mortalitet $(2,14)$. I følge Stubberud kan hyperglykemi også føre til et nedsatt immunforsvar og utvikling av nyresvikt og CIPNM (2).

Forskning har vist at intensiv insulinbehandling med blodsukkernivå mellom 4,6 til 6,1 mmol/l kan bidra til å forebygge CIPNM $(2,3,7,15)$. Gunstig blodsukkernivå har stor betydning for behandlingsresultatet og kan forbedre overlevelse (7). Stubberud anbefaler kontroll av blodsukker hver eller annenhver time ved hyperglykemi. Ved blodsukker på $10 \mathrm{mmol} / \mathrm{l}$ eller lavere, kan kontroller reduseres til hver fjerde time (2).

\section{Administrering av ernæring}

Stressmetabolismen ved kritisk sykdom fører til et betydelig tap av proteiner. Dette stammer hovedsakelig fra musklene. En viktig faktor for muskelmassetap hos kritisk syke pasienter er altså underskudd av protein. Ifølge Koukorikos og Kourkouta får kritisk syke pasienter vanligvis mindre enn 60 prosent av totalt kaloribehov (12). Optimal ernæringsterapi og tidlig mobilisering kan bidra til å begrense muskeltap og sykelighet hos risikopasienter. For å redusere nedbryting av muskelvev anbefales det å starte med ernæringstilførsel helst innen 48 timer hos akutt kritisk syke pasienter (2).

\section{इ «Enteral ernæring reduserer risikoen for infeksjon og sykelighet.»}


De fleste pasientene ernæres enteralt og/eller parenteralt. Enteral ernæring er å foretrekke framfor parenteral ernæring hos hemodynamiske stabile pasienter. Enteral ernæring reduserer risikoen for infeksjon og sykelighet (15). Kontraindikasjoner er ustabil hemodynamikk med systolisk blodtrykk under $60 \mathrm{~mm} \mathrm{Hg}$, alvorlige tarmbetennelser, postoperativ paralyse eller tarmfistel. En kombinasjon av enteral og parenteral ernæring kan være nødvendig for at intensivpasienten skal kunne få dekket sitt kaloribehov. Det anbefales å benytte ernæringsprotokoller for å vurdere og kvalitetssikre at pasienten får nødvendig ernæring (2).

\section{Tidlig mobilisering}

Tidlig mobilisering er et viktig tiltak for å forebygge CIPNM (2, 4, 5, 7, 12). Dette har vist til bedre livskvalitet i form av fysisk funksjon, sammenliknet med intensivpasienter som har blitt mobilisert i mindre grad (7). Stubberud anbefaler at pasienten mobiliseres ut av sengen så snart vedkommende er hemodynamisk stabil og ikke trenger sedasjon (2). Sykepleiere må vurdere om pasienten har ressurser for å mestre dette.

\section{Kontraindikasjoner}

Kriteriene som vurderes er blant annet pasientens respirasjon, sirkulasjon og psykisk tilstand (2). Kontraindikasjoner for tidlig mobilisering er følgende (2):

\section{Respirasjon:}

- Respirasjonsfrekvens mer enn 30-40/min

- Sp02 under 88 prosent i 5 minutter

- PEEP mer enn 1012 cm H2O

- Trykkontrollert respiratormodus med topptrykk mer enn $22 \mathrm{~cm} \mathrm{H} 2 \mathrm{O}$

- Markert usynkronisert samarbeid med respiratoren

- Fare for ekstubering

\section{Sirkulasjon:}


- Synkende arterielt middelblodtrykk (MAP)

- Hjertefrekvens mindre enn 50/min eller mer enn $130 /$ min i 5 minutter

- Intrakranielt trykk mer enn 20 mm Hg[a-L1]

- Nyoppstått hjertearytmi

- Risiko for myokardiskemi

\section{Psykisk tilstand:}

- Pasienten viser fysiske symptomer på stress

\section{Tilrettelegging}

Oppstart av fysioterapi og ergoterapi innen de første 48 timer gir funksjonell bedring ved utskriving til hjemmet og bidrar til forebygging av muskelatrofi (5, 12). Mobilisering i form av passive og aktive bevegelser kan starte så raskt intensivpasienten er hemodynamisk stabil (4). Øvelsene utføres avhengig av pasientens bevissthetsnivå (2). Mobilisering begynner ofte med passive øvelser, deretter aktive øvelser som stolsitting og gange $(16,17)$. Sengesykkel kan brukes til pasienter i både våken og sedert tilstand. Når pasienten er sedert, beveger sykkelen pedalene maskinelt. Den våkne pasienten trår selv.

\section{«Bevegelsen bidrar til å stimulere muskulaturen i bena.»}

Bevegelsen bidrar til å stimulere muskulaturen i bena (2). Dette bidrar til å bedre funksjon, og forebygge komplikasjoner som muskelforkortning, misdannelser og kontrakturer. Forskning viser at aktivitetsnivået hos kritisk syke pasienter fortsatt er lavt, til tross for at det foreligger studier som støtter tidlig mobilisering og viser at det er trygt å starte tidlig aktivitet hos denne pasientgruppen $(5,16,17)$. Parry \& Puthucheary nevner at barrierer for tidlig aktivitet og mobilisering av intensivpasienten kan være sedasjon, endotrakealtube og hemodynamisk ustabilitet (5). 
Det er anbefalt å tilrettelegge for teamarbeid omkring intensivpasienten, og opparbeide en positiv kultur for tidlig mobilisering. Pasientens nevrologiske utfall må ligge til grunn for valg av rehabilitering. Det er viktig å involvere fysioterapeuter tidlig under intensivoppholdet for å begrense konsekvensene av nevromuskulær svakhet hos kritisk syke (4).

\section{Behandling}

Det finnes ingen spesifikk behandling for CIPNM.

Foreslåtte tiltak som aggressiv behandling av sepsis, redusert dose- og behandlingsvarighet av muskelrelaksantia og kortikosteroider, rehabiliteringsprogram, ernæringstiltak, antioksidantterapi, testosteronderivater, veksthormon og immunglobulinterapi har vært forsøkt med varierende resultat (8). Dette understreker viktigheten av tidlig identifikasjon og forebygging.

\section{Oppsummering}

Pasienter med SIRS, sepsis, MODS, hyperglykemi og/eller langvarig respiratorbehandling har økt risiko for polynevromyopati. Tilstanden kan utvikle seg i løpet av få dager hos intensivpasienter. Kunnskap om risikopasienter, og forståelse for tilstanden er nødvendig for tidlig identifisering av symptomer, og for tidlig iverksetting av forebyggende tiltak.

Den henvises til artikkelen til Bente Noreide i Inspira 2 fra 2009: «CIPNM som komplikasjon hos intensivpasienten» (18). Nyere forskning (2010-2017) referert i vår artikkel viser samsvar med forskning som det henvises til i Noreide sin artikkel. Nyere forskning i forhold til de patofysiologiske prosessene ved utvikling av CIPNM, samt aktuelle differensialdiagnoser, kan bidra til tidligere identifisering og mulighet for forebygging av tilstanden.

\section{Referanser}


1. Mikkelsen ME, Netzer GN, Iwashyna T. Post intensive care syndrome (PICS). 2016. UpToDate. Tilgjengelig fra:

http://www.uptodate.com/contents/post-intensive-caresyndrome-pics?sourc...

(lastet ned 15.05.2016)

2. Stubberud DG. Sepsis. I: Gulbrandsen T, Stubberud DG (red.). Intensivsykepleie. Oslo: Akribe; 2015.

3. Hermans G, Van den Berghe G. Clinical review: intensive care unit acquired weakness. Crit Care 2015;19(1): 274.

4. Pattanshetty BR, Gaude GS. Critical illness myopathy and polyneuropathy- A challenge for physiotherapist in the intensive care units. India J Crit Care Med 2011;15(2):78-81.

5. Parry MS, Puthucheary AZ. The impact of extended bed rest on the musculoskeletal system in the critical care environment. Extrem Physiol Med 2015;4 (16).

6. Løseth S, Torbergsen A. Elektromyografi og nevrografi ved alvorlig nevromuskulær sykdom. Tidsskrift for Den norske legeforening 2013;133(2):174-8.

7. Larsson A, Rubertsson S. Intensivvård. Stockholm: Liber; 2012.

8. Zhou C, Wu L, Ni F, Wu J, Zhang H. Critical illness polyneuropathy and myopathy: a systematic review. Neural Regen Res 2014:9(1): 101-110. DOI: 10.4103/1673-5374.125337.

9. Supinski GS, Morris PE, Dhar S, Callahan LA, Diaphragm Dysfunction in Critical Illness. CHEST 2017. DOI: 10.1016/j.chest.2017.08.1157.

10. Ørn SS, Mjell J, Gansmo EB. Sykdom og behandling. Oslo: Gyldendal Norsk Forlag As; 2011. 
11. Stevens RD, Dowdy DW, Michael RK, Mendez PA, Pronovost PJ, Needham DM. Neuromuscular dysfunction acquired in critical illness: a systematic review. Int Care Med 2007;33 (11):1876-91.

12. Koukorikos K, Kourkouta L, Tsaloglidou A. Muscle Atrophy in Intensive Care Unit Care. Acta Inform Med 2014;2286:406-10.

13. Gulbrandsen T. Sedasjon I: Gulbrandsen T, Stubberud DG (red.). Intensivsykepleie. Oslo: Akribe;2012.

14. Stapleton RD, Heyland KD. Glycemic control and intensive insulin therapy in critical illness. 2016 UpToDate. Tilgjengelig fra: Glycemic control and intensive insulin therapy in critical illness (lastet ned 15.06.2016)

15. Van den Berghe G, Schoonheydt K, Becx P, Bruyninchx F, Wouters PJ. Insulin therapy protects the central and peripheral nervous system of intensive care patients. Neurology 2005; 64(8):348-53.

16. Bukowiec C. Optimizing nutrition therapy to enhance mobility in critically ill patients. Crit Care Nurs 2013;36 (1):28-36.

17. Doherty N, Steen D. Critical illness polyneuromyopathy (CIPNM); rehabilitation during critical illness. Therapeutic options in nursing to promote recovery: A review of the literature. Int Crit Care Nurs 2010;26(6):353-62.

18. Noreide B. CIPNM som komplikasjon til intensivpasienten. Inspira. 2009;2. Hentet fra: https://www.alnsf.no/inspira/2009/5-inspira-20092/file (lastet ned 24.09.17) 